\title{
Protective effect of KIR3DS1 in asymptomatic HIV-1 seroconverters towards AIDS
}

\author{
M Stalinraja', N Kalyanaraman', P Leishman', M Suresh², M Jayalakshmi ${ }^{*}$ \\ From First International Science Symposium on HIV and Infectious Diseases (HIV SCIENCE 2012) \\ Chennai, India. 20-22 January 2012
}

\section{Background}

The extreme variability at the Killer cell Immunoglobulin like Receptor (KIR) expressed on the surface of natural killer cells interacts with Human Leukocyte Antigen (HLA) Class I appear to play a crucial role in the outcome against viral infection. The combination of HLA/KIR gene products either individually or collectively have been implicated in the control of HIV-1 in various populations. Objective of this immunogenetic case-control study is to determine the association between KIR3DS1 and HIV-1 asymptomatism.

\section{Methods}

31 treatment naive HIV-1 asymptomatic (>3yrs without disease progression) and 31 HIV-1 seronegative ethnic matched healthy controls were recruited for this case control study. Genomic DNA was extracted from peripheral blood by salting out procedure and KIR genotyping was performed for $16 \mathrm{KIR}$ genes (Activating, Inhibitory and Pseudogenes) by Duplex PCR sequencespecific primer method.

\section{Results}

Overall, we observed $66.12 \%$ of individuals with B KIR haplotype among case and controls group. Among the 16 KIR genes were typed KIR3DS1 (Activating KIR gene) shows significant variation among HIV asymptomatic individuals was $74.2 \%$ whereas $54.8 \%$ among controls.

\section{Conclusion}

Since, KIR3DS1 is well known for its effect on direct viral containment, presence of higher KIR3DS1 is one of

\footnotetext{
* Correspondence: jayalakshmimk11@yahoo.com

'Dept of Immunology, School of Biological Sciences, Madurai Kamaraj University, Madurai - 21, India

Full list of author information is available at the end of the article
}

the possible reasons for asymptomatism among this study cohort.

\section{Author details}

'Dept of Immunology, School of Biological Sciences, Madurai Kamaraj University, Madurai - 21, India. ${ }^{2}$ ART Centre, Govt Theni Medical College and Hospital, Theni, India.

Published: 4 May 2012

\section{doi:10.1186/1471-2334-12-S1-P69}

Cite this article as: Stalinraja et al:: Protective effect of KIR3DS1 in asymptomatic HIV-1 seroconverters towards AIDS. BMC Infectious Diseases 2012 12(Suppl 1):P69.

\section{Submit your next manuscript to BioMed Central and take full advantage of: \\ - Convenient online submission \\ - Thorough peer review \\ - No space constraints or color figure charges \\ - Immediate publication on acceptance \\ - Inclusion in PubMed, CAS, Scopus and Google Scholar \\ - Research which is freely available for redistribution \\ Submit your manuscript at www.biomedcentral.com/submit}

